\title{
Præsteslægten Boetius' Oprindelse.
}

\section{Af Johan Hvidtfeldt.}

Slægten Boetius eller Boysen, som dens danske navn lyder, spillede i det 16. og følgende aarhundreder en stor rolle i det kirkelige liv i Sønderjylland, især i Haderslev amt.

Hvor slægten stammer fra, har hidtil været ukendt. En overlevering vilde vide, at den var kommet fra Italien, men navnet Boysen tyder dog afgjort paa, at Slesvig er dens hjemstavn. Slægtens historieskriver har gættet paa, at dens ældste kendte medlem Laurens Boysen, der var sognepræst i Vilstrup fra omkring 1524 indtil 1547, stammede fra Hejsager, og har fremfort forskellige vidnesbyrd, der kunde tyde i den retning.') Et gammelt pergamentsbrev, der findes i det sønderjydske Landsarkiv,") giver dog den rigtige løsning af gaaden. Brevet er et tingsvidne, udstedt paa Vis herreds allemandsting den 6. februar 1539 af Boie Jessen, herredsfoged i Vis herred, og "gantzem gemenen Harde" til Tammes Boyssen i Kollund. Det fremgaar heraf, at hr. Laurens i Vilstrup har skødet Tammes Boyssen en broderdel i den bondegaard (d.v.s. selvejergaard) i Kollund, som demme boede $i$. Ligeledes har Hinrick Kocke i Flensborg skødet den samme en broderdel paa afdøde Hans Boyssens vegne, ligesom Boye Negelssen (Nielsen) i Hokkerup og Hans Oluffssen i Hokkerup hver har skødet ham en søsterdel. Der kan herefter ingen tvivl være om, at Laurens Boysen, slægtens stamfader, er født i Kollund, hvor hans broder Tammes endnu 1539 boede paa den bondegaard, hvor de antagelig begge har set dagens lys. En tredie broder Hans er død paa dette tidspunkt, og to søstre, hvis navne ikke kendes, er blevet gift med mænd fra Hokkerup, der ligger i nærheden.

Et andet nærliggende spørgsmaal er, hvem faderen til disse fem søskende var. I 1483 nævnes en Bo eller Boye Jensen i Kol-

\footnotetext{
1) Sønderjydske Aarbøger 1927. $254 \mathrm{f}$.

2) Pergamentsloreve: Kollund (foræret Landsarkivet af Pastor Clausen).
} 
lund. $\left.{ }^{3}\right)$ Han kan være faderen. Navnene kunde iøvrigt tyde paa, at der var slægtskabsforbindelse med den kendte herredsfogedslægt i Kollund, hvis stamfader Jes Thomsen, fader til den ovennævnte herredsfoged Boie Jessen, i 1488 blev benaadet med skjold og hjelm af kong Hans.") Under grev Gerhards oprør mod broderen Christian den første holdt han fast ved kongens sag i modsætning til de ovrige af herredets behoere. Han søgte tilflugt paa det kongelige slot Duborg ved Flensborg. I et halsløsningsregister fra Flensborg amt 1472 nævnes Jesse Tamssen i Kollund. Der opføres ingen sum for ham, men det hedder om ham, at han "var med os paa borgen ". ${ }^{5}$ ) Den senere benaadning skal sikkert ses $\mathrm{i}$ forbindelse med denne begivenhed. Iøvrigt maa han have været en ret ung mand, da han sad med kongens mænd paa Duborg. Thi endnu 1527 nævnes han som herredsfoged i Vis herred. ${ }^{\circ}$ )

Aabenraa, den 3. januar 1940.

3) Falkenstjerne og Hurie: Sønderjydske Skatte- og Jordebøger 219, Repertoriet 2. r. III 318; jvnf. Sejdelin: Diplomatarium Flensborgense I 447 .

4) Repertoriet 2. r. III 634; Sønderjydsk Maanedsskrift 1931. 137 ff.; 1936. 244 ff.

$\left.{ }^{5}\right)$ Kongens Arkiv: Flensborg Amts Regnskaber 1472-1499 (Rigsarkivet).

$\left.{ }^{\circ}\right)$ Zeitschrift der Gesell. für Schlesw.-Holst. Geschichte VIII 143. 